\title{
Impact Assessment of Phosphogypsum Leachate on Groundwater of Sfax-Agareb (Southeast of Tunisia): Using Geochemical and Isotopic Investigation
}

\author{
Samira Melki (iD) and Moncef Gueddari \\ Laboratory of Geochemistry and Environmental Geology, Department of Geology, Faculty of Sciences of Tunis, \\ University of Tunis El Manar, 2092 Tunis, Tunisia
}

Correspondence should be addressed to Samira Melki; melkisamiralefi@hotmail.fr

Received 12 November 2017; Accepted 8 January 2018; Published 31 January 2018

Academic Editor: Adina Negrea

Copyright (C) 2018 Samira Melki and Moncef Gueddari. This is an open access article distributed under the Creative Commons Attribution License, which permits unrestricted use, distribution, and reproduction in any medium, provided the original work is properly cited.

\begin{abstract}
The production of phosphoric acid by the Tunisian Chemical Group, in Sfax, Tunisia, led to the degradation of the groundwater quality of the Sfax-Agareb aquifer mainly by the phosphogypsum leachates infiltration. Spatiotemporal monitoring of the quality of groundwater was carried out by performing bimonthly sampling between October 2013 and October 2014. Samples culled in the current study were subject to physicochemical parameters measurements and analysis of the major elements, orthophosphates, fluorine, trace metals, and stable isotopes $\left({ }^{18} \mathrm{O},{ }^{2} \mathrm{H}\right)$. The obtained results show that the phosphogypsum leachates infiltration has a major effect on the downstream part of the aquifer, where the highest values of conductivity, $\mathrm{SO}_{4}{ }^{2-}$, Ortho- $\mathrm{P}$, and $\mathrm{F}^{-}$, and the lowest $\mathrm{pH}$ were recorded. In addition, these results indicated that phosphogypsum leachates contained much higher amount of $\mathrm{Cr}$, $\mathrm{Cd}, \mathrm{Zn}, \mathrm{Cu}, \mathrm{Fe}$, and $\mathrm{Al}$ compared to the groundwater. Spatiotemporal variation of the conductivity and concentrations of major elements is linked to the phosphogypsum leachates infiltration as well as to a wide range of factors such as the natural conditions of feeding and the water residence time. Contents of ${ }^{18} \mathrm{O}$ and ${ }^{2} \mathrm{H}$ showed that the water of the Sfax-Agareb aquifer undergoes a large scale evaporation process originated from recent rainfall.
\end{abstract}

\section{Introduction}

Groundwater pollution proves to be potentially threatening as it puts at jeopardy the hygienic integrity of a huge water reserve. The intensification of industrial activities, as well as the diversification of the storage modes of by-products production, makes groundwater resources vulnerable and can be considered as the main factors responsible for groundwater pollution. The groundwater quality is equally important as its quantity to the suitability of water for various purposes [1]. Variation of groundwater quality in different regions is a function of physical and chemical parameters that are greatly influenced by geological formations and anthropogenic activities [2]. Groundwater resources of the Mediterranean coastal plains in the southern bank of the basin (Middle East and North Africa) show a qualitative and quantitative deterioration developing in time [3-5] resulting in natural constraints and anthropological activities.
In Tunisia, climatic constraints, with a moderate rainfall contribution, which are unequally distributed in the space and irregular in time, as well as a strong evaporation power, make water resources limited. Socioeconomic development and the spread of industrialization have led to pressuring the resources and increasing the demand. Thus, the water supply, estimated at $472 \mathrm{~m}^{3} /$ inhabitant in 2010 , will decrease to $315 \mathrm{~m}^{3}$ /inhabitant in 20 years [6]. In addition, water pollution related to the increased water use, urban and industrial areas, and agricultural intensification is increasingly threatening both the quality and the amount of groundwater resources. This phenomenon's implications are felt in the satisfaction of water demand as well as water cost.

Urban, industrial, and tourist centers have been developing along the eastern coast of Tunisia. Several industries are located in Sfax area, especially those of the Tunisian Chemical Group (TCG) for the enrichment and transformation of natural phosphate. The TCG activity focuses primarily on 
the chemical fertilizers and phosphoric acid production, by the fluorapatite transformation. This production model generates gaseous emissions, liquid discharges, and huge amounts of phosphogypsum (PG), issued from the treatment of phosphate rock with sulfuric acid [7-14]. This chemical reaction is illustrated in the equation below:

$$
\begin{array}{cc}
\mathrm{Ca}_{10}\left(\mathrm{PO}_{4}\right)_{6} \mathrm{~F}_{2}+10 \mathrm{H}_{2} \mathrm{SO}_{4}+20 \mathrm{H}_{2} \mathrm{O} & \rightarrow 10 \mathrm{CaSO}_{4} \cdot 2 \mathrm{H}_{2} \mathrm{O}+6 \mathrm{H}_{3} \mathrm{PO}_{4}+2 \mathrm{HF} \\
\text { Fluorapatite } & \text { Phosphogypsum }
\end{array}
$$

The main environmental contamination associated with PG dump is fluoride, sulfate, calcium, phosphate, and trace elements or radionuclides movement into groundwater [7]. The scope of this study is to appreciate the PG leachates infiltration effect on the Sfax-Agareb aquifer and to identify the factors and the phenomena, which explain the spatial and the temporal variation of the groundwater quality's assessment parameters.

\section{Description of the Study Area}

The study area is situated in the coast of Sfax, where the TCG plant, a discharge of domestic waste, and a station of wastewater treatment are located (Figure 1). The study area is under the influence of the Mediterranean climate, relatively humid and temperate, with cold and rainy seasons, between December and March, and dry and hot seasons, between June and October. The average annual precipitation is around $250 \mathrm{~mm}$ [15]. The mean annual temperature is $20^{\circ} \mathrm{C}$ [16]. The outcropping geological formations (Figure 2) are composed of sandy clays rich in gypsum and silty sand [17], of MioPliocene to lower Quaternary age [18]. The TCG site takes place in an area covered by recent alluvium, made up by sand and calcareous gypsum crusts. The Sfax-Agareb aquifer, in this case study, is constituted by two sandy levels, ranging from 2 to $5 \mathrm{~m}$ in terms of thickness (Figure 3), separated by clay and sandy layers [19]. This aquifer is recharged by meteoric water. Groundwater flow in the study area is Northwest to Southeast.

\section{Materials and Methods}

3.1. Groundwater Sampling and Analysis. Groundwater samples were culled bimonthly from ten piezometers in the phreatic aquifer of Sfax-Agareb, between October 2013 and October 2014 (Figure 1). Monitoring piezometers purging was accomplished by using a submersible pump. The purge was achieved when the $\mathrm{pH}$ and the electrical conductivity (EC) of the ground water have been stabilized. Samples taken were acidified using $0.1 \mathrm{~N} \mathrm{HNO}_{3}$ and kept at $4^{\circ} \mathrm{C}$ until the analysis was thoroughly carried out aiming to optimize the accuracy of the obtained findings. The samples were analyzed for the following parameters, which include $\mathrm{EC}, \mathrm{pH}$, $\mathrm{T}$, dissolved $\mathrm{O}_{2}, \mathrm{Cl}^{-}, \mathrm{SO}_{4}{ }^{2-}, \mathrm{HCO}_{3}{ }^{-}, \mathrm{Na}^{+}, \mathrm{K}^{+}, \mathrm{Mg}^{2+}, \mathrm{Ca}^{2+}$, $\mathrm{F}^{-}$, and orthophosphates (Ortho-P). EC, $\mathrm{pH}$, and dissolved oxygen were measured in the field using calibrated portable digital meters. Calcium, magnesium, sodium, and potassium were identified using atomic absorption spectrometer. Carbonate, bicarbonate, chloride, and sulfate were determined by standard titration methods [21]. Orthophosphates were analyzed by absorption colorimeter [21] and fluoride ion concentrations were measured by specific electrode [21]. The accuracy of the chemical analysis was determined by calculating the ionic balance error, which was generally less than $5 \%$. The trace elements were analyzed using inductivity coupled plasma-atomic emission spectrophotometer (ICPAES). A summary of the physicochemical and chemical data of all the investigated groundwater during the period 20132014 is presented in Table 1. Stable isotope analysis of $\delta^{2} \mathrm{H}$ and $\delta^{18} \mathrm{O}$ was performed by cavity ring down spectrometry using a Picarro L2120 [22] at the laboratory of Applied Geology and Geo-Environment, Ibn Zohr University, Morocco.

3.2. Multivariate Statistical Analysis. The application of multivariate statistical analysis offers a clearer understanding of water quality and enables comparison of the different water samples [23] and making of correlations between chemical parameters and groundwater samples, respectively. The different elements combination (samples and parameters) is used in order to characterize the hydrogeochemical variation of the Sfax-Agareb aquifer, in the site of TCG, in order to predict the future of the PG leachate percolation as well as to assess the spatial variation of the groundwater chemical composition. In this study, only the principal component analysis (PCA) was carried. PCA of the experimental data has been performed using the Xlstat.

\section{Results and Discussion}

4.1. Characterization of $P G$ Leachate. On global scale, $15 \%$ of the PG production is recycled while large quantities are stored in the factories vicinity, which are disposed mostly in big piles. They are located in coastal areas with phosphoric acid plants nearby, both as dry or wet staking and without treatment [24]. Since PG waste is generally transported and disposed as an aqueous slurry, dissolution/leaching of the chemical elements present in the PG can occur. Dissolved elements may be deposited in nearby soils or transferred to groundwater [25]. Thus, it is important to know the characteristics of leachate obtained from the PG waste dump. Table 2 lists the chemical composition of a typical sample of PG leachate sampling from the GCT site of Sfax. The leachate has a very low $\mathrm{pH}$ (1.3) and high concentrations of fluoride $(3500 \mathrm{mg} / \mathrm{L})$, orthophosphate $\mathrm{H}_{2} \mathrm{PO}_{4}{ }^{-}(6730 \mathrm{mg} / \mathrm{L})$, and toxic elements $(\mathrm{Cd}, \mathrm{Cr}$, and $\mathrm{Zn})$. For all the analyzed elements, the levels exceeded the Tunisian standard for liquid discharge (NT 106-002). 


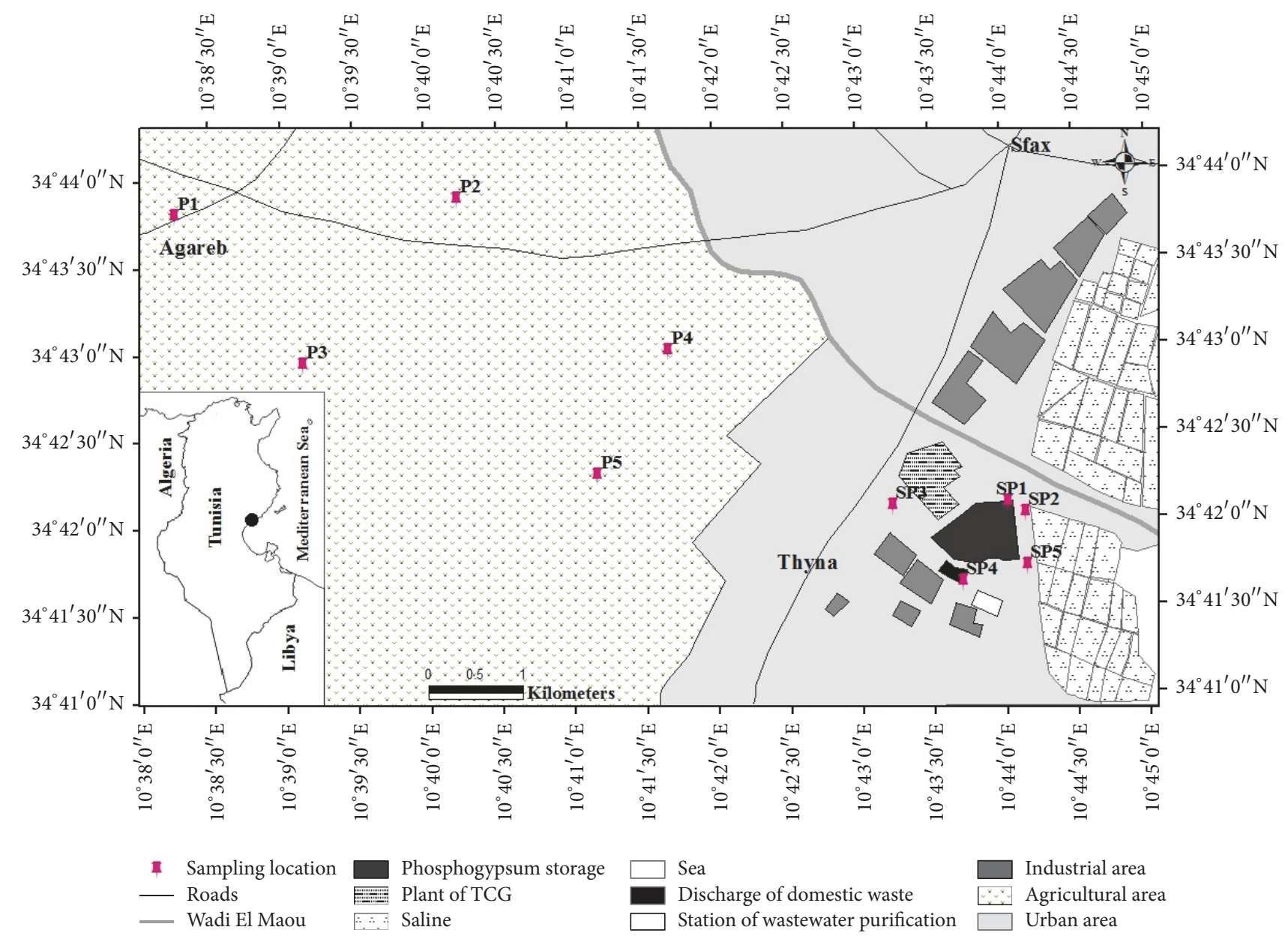

FIGURE 1: Location map of the study area showing piezometers and reference well sampled for groundwater analysis.

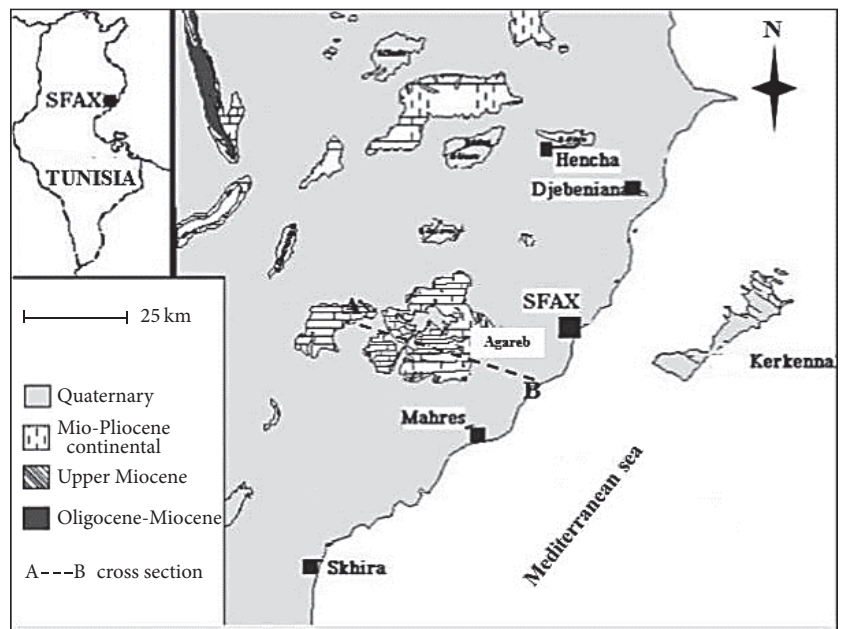

FIGURE 2: Geological map of Sfax [20].

\subsection{Groundwater Geochemical Characteristics and Evolution}

4.2.1. Physicochemical Parameters. Groundwater temperature tends to vary from 10.1 to $13.9^{\circ} \mathrm{C}$. The spatiotemporal variation of this parameter did not show any audible alternation during the whole period of testing (Figure 4(a)). The $\mathrm{pH}$
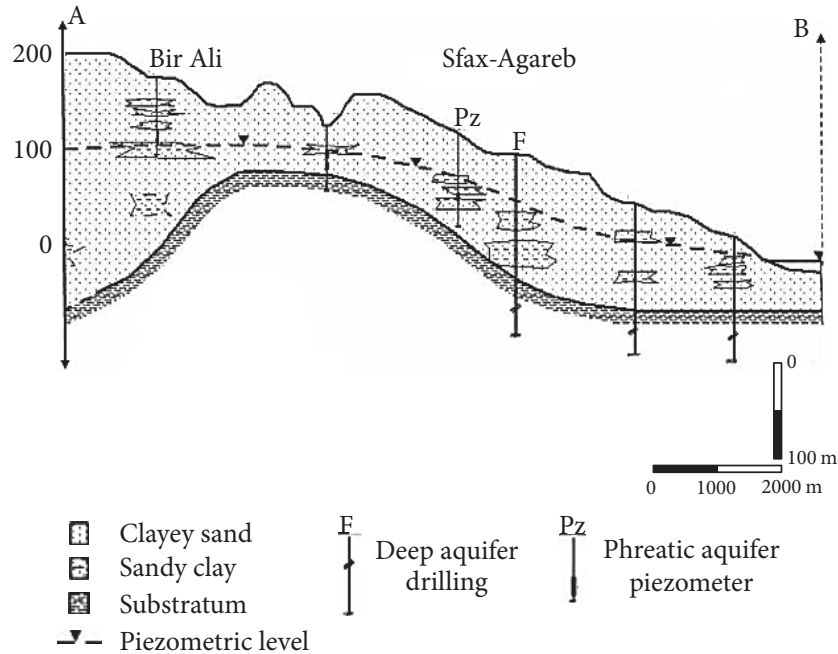

FIGURE 3: Hydrogeological cross-section along transect $\mathrm{AB}$, as indicated in Figure 2 [19].

values remain in the range of 5.18-7.95 as detailed. The lowest values were measured near PG storage site (SP1 and SP4), whereas in the upstream part of the study area (P1, P2, P3, $\mathrm{P} 4, \mathrm{P} 5$, and SP1) they were mainly neutral to slightly alkaline 
TABLE 1: Chemical composition of groundwater samples

\begin{tabular}{|c|c|c|c|c|c|c|c|c|c|c|c|c|c|}
\hline \multirow{2}{*}{$\begin{array}{l}\text { Months } \\
\text { Parameters }\end{array}$} & \multirow{2}{*}{ Unit } & \multicolumn{2}{|c|}{ Oct 13} & \multicolumn{2}{|c|}{ Jan 14} & \multicolumn{2}{|c|}{ Mar 14} & \multicolumn{2}{|c|}{ May 14} & \multicolumn{2}{|c|}{ Aug 14} & \multicolumn{2}{|c|}{ Oct 14} \\
\hline & & Min & Max & Min & Max & Min & Max & Min & Max & Min & Max & Min & Max \\
\hline$T$ & ${ }^{\circ} \mathrm{C}$ & 12.1 & 13.9 & 10.1 & 12.8 & 11 & 11.7 & 11.10 & 12.20 & 12.2 & 13.2 & 12.00 & 13.1 \\
\hline $\mathrm{pH}$ & $\mathrm{mg} / \mathrm{L}$ & 5.18 & 7.74 & 5.75 & 8.1 & 5.58 & 7.95 & 5.56 & 7.85 & 5.2 & 7.79 & 5.50 & 7.76 \\
\hline O2dissolved & $\mathrm{mg} / \mathrm{L}$ & 0.9 & 2.15 & 0.9 & 4.2 & 0.8 & 3.5 & 0.80 & 3.12 & 0.7 & 2.9 & 0.50 & 2.8 \\
\hline EC & $\mu \mathrm{s} / \mathrm{cm}$ & 2100 & 33200 & 1590 & 33000 & 1650 & 32600 & 1680 & 34300 & 1800 & 34700 & 1900 & 34900 \\
\hline $\mathrm{K}^{+}$ & $\mathrm{mg} / \mathrm{L}$ & 2.7 & 22.70 & 2.25 & 19 & 2.15 & 19.6 & 2.60 & 19.50 & 2.5 & 21.2 & 2.7 & 23.68 \\
\hline $\mathrm{Na}^{+}$ & $\mathrm{mg} / \mathrm{L}$ & 111.5 & 6965 & 139.4 & 6760 & 142 & 6300 & 115.16 & 6124 & 198 & 6600 & 195 & 6515 \\
\hline $\mathrm{Ca}^{2+}$ & $\mathrm{mg} / \mathrm{L}$ & 59 & 986 & 49 & 904 & 50 & 851 & 54.36 & 1075 & 51 & 1080 & 58 & 1020 \\
\hline $\mathrm{Mg}^{2+}$ & $\mathrm{mg} / \mathrm{L}$ & 37 & 945 & 22.5 & 920 & 24 & 940 & 29.75 & 1085 & 25 & 1050 & 35 & 1080 \\
\hline $\mathrm{Cl}^{-}$ & $\mathrm{mg} / \mathrm{L}$ & 110.6 & 5480 & 104.3 & 5396 & 101 & 5372.5 & 151 & 5475 & 135.5 & 5810 & 112 & 5632.5 \\
\hline $\mathrm{HCO}_{3}{ }^{-}$ & $\mathrm{mg} / \mathrm{L}$ & 256.4 & 9143.9 & 195.2 & 9661.5 & 271 & 9533.9 & 199.20 & 8533.9 & 245 & 9313.9 & 255 & 9973 \\
\hline $\mathrm{SO}_{4}{ }^{2-}$ & $\mathrm{mg} / \mathrm{L}$ & 215 & 4396.1 & 201.5 & 4295.7 & 204 & 4352.9 & 261.25 & 4543.7 & 210 & 4857.3 & 210 & 4948.5 \\
\hline Ortho-P & $\mathrm{mg} / \mathrm{L}$ & 2.15 & 67.3 & 2.5 & 81.7 & 2.7 & 71.00 & 1.90 & 136.65 & 1.5 & 92 & 1.25 & 114.95 \\
\hline $\mathrm{F}^{-}$ & $\mathrm{mg} / \mathrm{L}$ & 0.6 & 26 & 0.6 & 27 & 0.50 & 19.00 & 0.50 & 29.00 & 0.5 & 17 & 0.6 & 19 \\
\hline $\mathrm{Al}$ & $\mathrm{mg} / \mathrm{L}$ & 0.02 & 1.8 & 0.03 & 1.57 & 0.03 & 0.90 & 0.06 & 0.98 & 0.02 & 0.96 & 0.03 & 0.97 \\
\hline $\mathrm{Zn}$ & $\mathrm{mg} / \mathrm{L}$ & 0.03 & 1.46 & 0.02 & 1.41 & 0.02 & 1.44 & 0.03 & 1.47 & 0.04 & 1.51 & 0.03 & 1.05 \\
\hline
\end{tabular}

(Figure 4(b)). The contents of dissolved $\mathrm{O}_{2}$ fluctuate between 0.5 and $4.2 \mathrm{mg} / \mathrm{L}$. The spatial distribution of these values shows an increase as we move further from the site of PG storage, in the direction of groundwater flow (Figure 4(c)). The temporal variation of this parameter depends on the control of the depth of the water table, the recharge rate, the transfer speed of oxygenated water from the upstream to the downstream, and the temperature. The electrical conductivity (EC) ranged from $1590 \mu \mathrm{s} / \mathrm{cm}$ to $34900 \mu \mathrm{s} / \mathrm{cm}$ at $25^{\circ} \mathrm{C}$. The highest value characterizes sampled water in the southwest (SP4) and in the southeast (SP5) of the study area, whereas the lowest EC was the main feature of the P1, P2, and P3 piezometers (Figure $4(\mathrm{~d})$ ). This spatial variation in the flow direction of the phreatic aquifer (North-West to Southeast) is related to sea water intrusion and to the infiltration of both PG leachate and saline brines. The highest values are recorded during the dry season (May, August, and October), while the lowest values are recorded during the wet season (January and March). The temporal variation is due to the dilution effect with fresh water in the recharge areas during the wet season and the direct evaporation, during the dry season, in areas with low hydraulic gradient and poor permeability [26].

4.2.2. Origin and Geochemical Behavior of Major Elements. Concentrations of $\mathrm{SO}_{4}{ }^{2-}, \mathrm{HCO}_{3}{ }^{-}$, and $\mathrm{Ca}^{2+}$ ranged from 201.5 to $4948.5 \mathrm{mg} / \mathrm{L}$, from 195.2 to $9973 \mathrm{mg} / \mathrm{L}$, and from 49 to $1080 \mathrm{mg} / \mathrm{L}$, respectively. During the study period, the higher contents of $\mathrm{HCO}_{3}{ }^{-}$and $\mathrm{Ca}^{2+}$ were registered in SP4 piezometer, whereas the optimal concentrations of $\mathrm{SO}_{4}{ }^{2-}$ were measured in SP5 piezometer, which is located in the east of the PG storage.

Understanding of the water-rock interaction and the associated reactions in the aquifer is essential to identify the variability of $\mathrm{Ca}^{2+}, \mathrm{HCO}_{3}{ }^{-}$, and $\mathrm{SO}_{4}{ }^{2-}$ concentrations. The calculation of ions activities and the appreciation of the saturation state with respect to calcite and gypsum help
TABLE 2: Chemical composition of PG leachate in May 2014.

\begin{tabular}{lcc}
\hline Parameters & Leachate PG & $\begin{array}{c}\text { Tunisian standard for liquid } \\
\text { discharge (NT 106-002) }\end{array}$ \\
\hline $\mathrm{EC}$ & 22700 & $6.5-8.5$ \\
$\mathrm{pH}$ & 1.3 & 3 \\
$\mathrm{~F}$ & 3500 & 0.05 \\
$\mathrm{H}_{2} \mathrm{PO}_{4}{ }^{-}$ & 6730 & 500 \\
$\mathrm{Ca}^{2+}$ & 1357 & 600 \\
$\mathrm{SO}_{4}{ }^{2-}$ & 3240 & 200 \\
$\mathrm{Mg}^{2+}$ & 198 & 600 \\
$\mathrm{Cl}^{-}$ & 1560 & 500 \\
$\mathrm{Na}^{+}$ & 2000 & 50 \\
$\mathrm{~K}^{+}$ & 139 & 0.5 \\
$\mathrm{Cr}$ & 1.2 & 0.005 \\
$\mathrm{Cd}$ & 0.8 & 5 \\
$\mathrm{Zn}$ & 4 & 5 \\
$\mathrm{Al}$ & 4 & 0.5 \\
$\mathrm{Cu}$ & 0.5 & 1 \\
$\mathrm{Fe}$ & 6 &
\end{tabular}

Units in $\mathrm{mg} / \mathrm{L}$ except $\mathrm{pH}$ and $\mathrm{EC}(\mu \mathrm{S} / \mathrm{cm})$.

to assess the chemical composition of the groundwater and to identify the controlling geochemical reactions [27]. The flowing dissolution reactions $\left(T=25^{\circ} \mathrm{C}\right.$ and $\left.P=1 \mathrm{~atm}\right)$ are considered:

$$
\begin{aligned}
& \text { Calcite: } \mathrm{CaCO}_{3}+\mathrm{H}^{+} \leftrightarrow \mathrm{Ca}^{2+}+\mathrm{HCO}_{3}{ }^{-} \\
& \log K_{\mathrm{ps}}=\log a\left[\mathrm{Ca}^{2+}\right]+\log a\left[\mathrm{HCO}_{3}{ }^{-}\right]+\mathrm{pH}=1.71 \\
& {[28]} \\
& \text { Gypsum: } \mathrm{CaSO}_{4} \cdot 2 \mathrm{H}_{2} \mathrm{O} \leftrightarrow \mathrm{Ca}^{2+}+\mathrm{SO}_{4}{ }^{2-}+2 \mathrm{H}_{2} \mathrm{O} \\
& \log K_{\mathrm{ps}}=\log a\left[\mathrm{Ca}^{2+}\right]+\log a\left[\mathrm{SO}_{4}{ }^{2-}\right]+2 \log a\left[\mathrm{H}_{2} \mathrm{O}\right]= \\
& -4,61[29]
\end{aligned}
$$




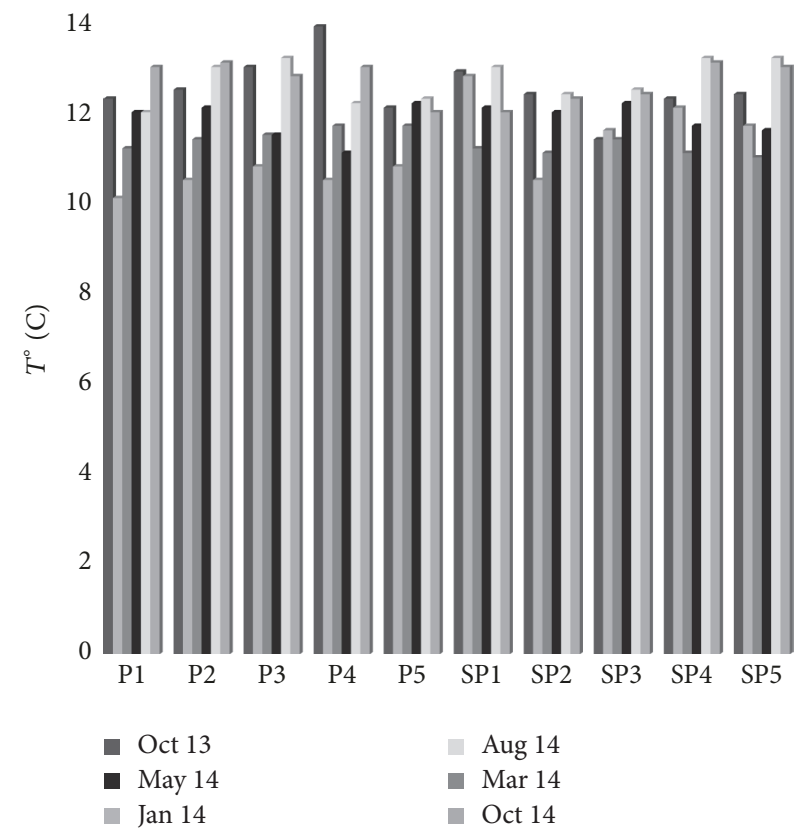

(a)

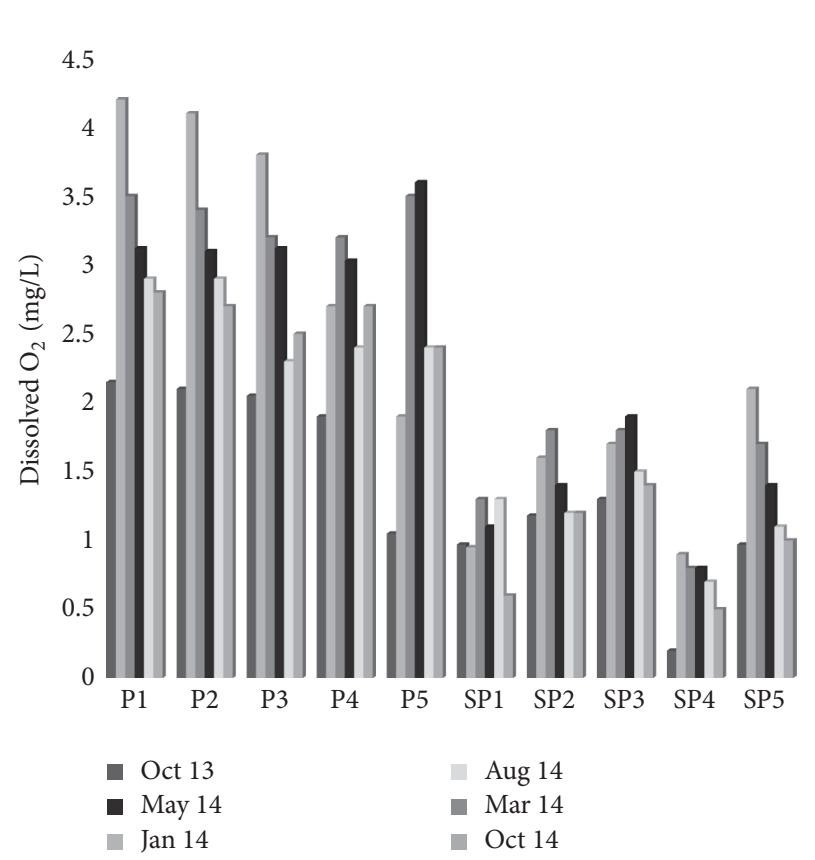

(c)

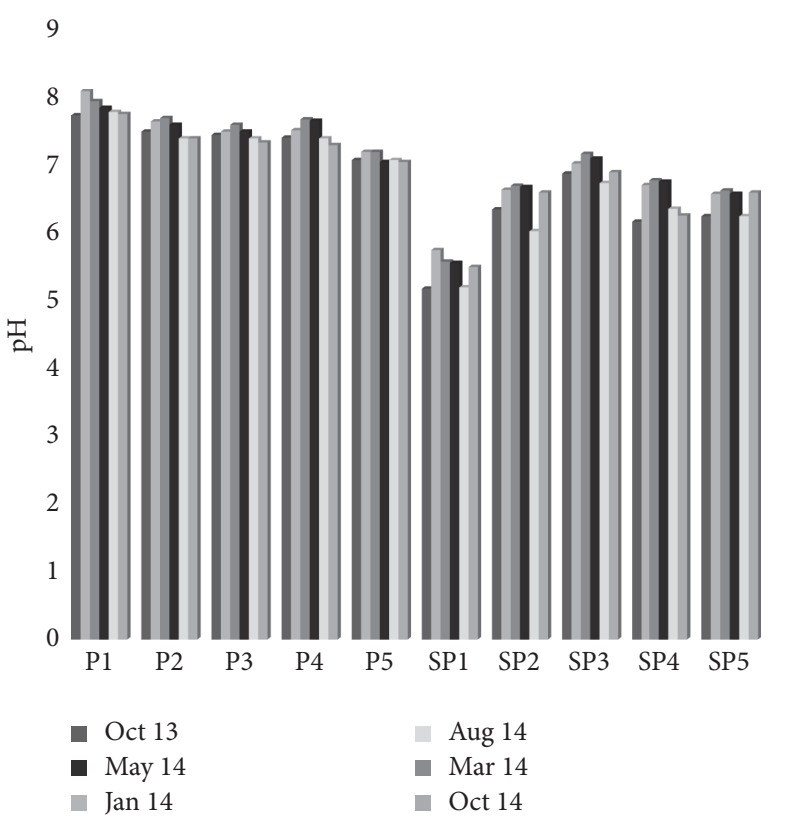

(b)

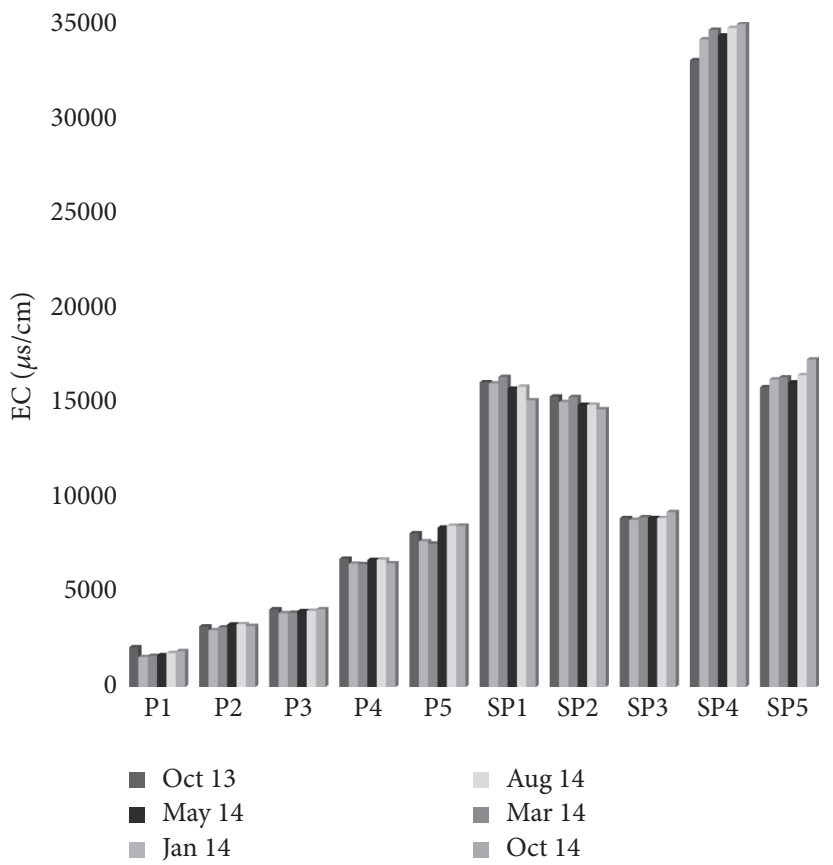

(d)

FIGURE 4: Distribution of temperature (a), $\mathrm{pH}(\mathrm{b})$, dissolved $\mathrm{O}_{2}(\mathrm{c})$, and EC (d) in groundwater of Sfax-Agareb aquifer.

In order to calculate activities and ion activity product, the computer code PHREEQC [30] is used. The relation between the solubility product constant $\left(K_{\mathrm{ps}}\right)$ and the ion activities product (IAP) is given by the saturation index (SI) defined as

$$
\mathrm{SI}=\log \left(\frac{\mathrm{IAP}}{K_{\mathrm{ps}}}\right)
$$

When SI $<0$ water is considered undersaturated, whereas when SI $>0$ water is considered oversaturated compared to the mineral.

The results show that the groundwater of the upstream zone of the phreatic aquifer (P1, P2, P3, P4, P5, and SP3) is undersaturated compared to gypsum (Figure 5), while, in the downstream zone, water with low $\mathrm{pH}$ (SP1, SP2, SP4, and SP5) is oversaturated. Compared to this mineral, the 


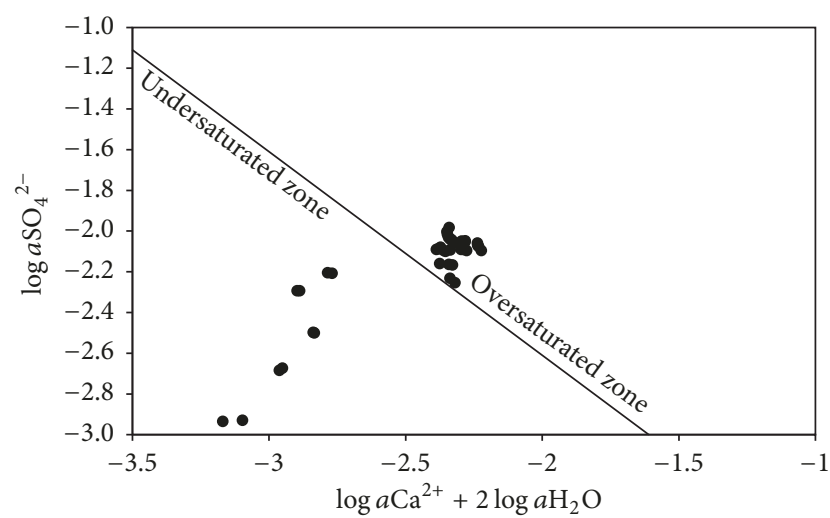

FIGURE 5: Equilibrium diagram of gypsum.

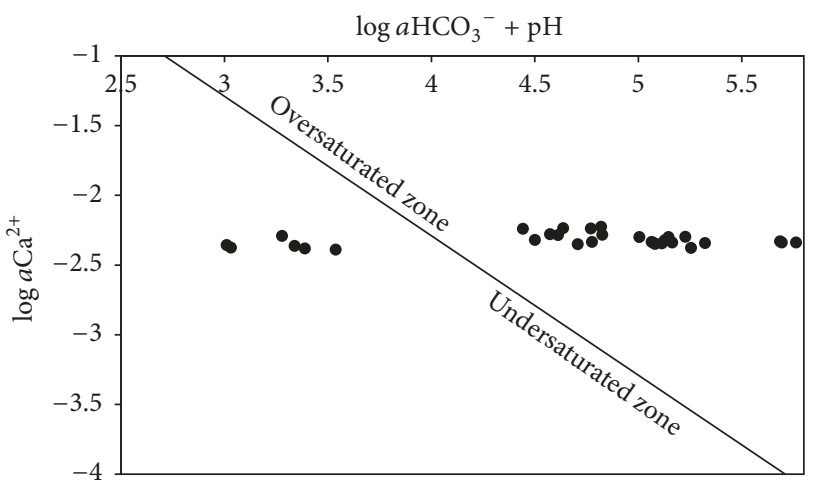

FIgURE 6: Equilibrium diagram of calcite.

groundwater oversaturation, in the TCG site, is explained by the acid PG leachate infiltration, which promotes the dissolution of gypsum and the complexation of $\mathrm{Ca}^{2+}$ and $\mathrm{SO}_{4}{ }^{2-}$ ions. The equilibrium diagram $\mathrm{Ca}^{2+}-\mathrm{HCO}_{3}{ }^{-}$(Figure 6) shows that groundwater, except for SP1 near the PG dump, is widely oversaturated compared to calcite. SP1 water is highly acidic, which prevents saturation with respect to calcite.

The sodium and chloride concentrations varied from 111.5 to $6965 \mathrm{mg} / \mathrm{L}$ and from 101 to $5810 \mathrm{mg} / \mathrm{L}$, respectively. The $\mathrm{Na}^{+}-\mathrm{Cl}^{-}$plot exhibits three water groups (Figure 7):

(i) Group I: $\mathrm{Na}^{+}$and $\mathrm{Cl}^{-}$contents are less than $50 \mathrm{mmol} / \mathrm{L}$ and $30 \mathrm{mmol} / \mathrm{L}$, respectively. It concerns water of the upstream part of the study area (P1, P2, $\mathrm{P} 3$, and $\mathrm{P} 4)$.

(ii) Group II: $\mathrm{Na}^{+}$and $\mathrm{Cl}^{-}$concentrations range from 50 to $120 \mathrm{mmol} / \mathrm{L}$ and from 30 to $100 \mathrm{mmol} / \mathrm{L}$, respectively. This group encompasses water of the downstream zone, near the evaporation ponds (SP1, SP2, SP3, and SP5).

(iii) Group III: $\mathrm{Na}^{+}$and $\mathrm{Cl}^{-}$contents are greater than $250 \mathrm{mmol} / \mathrm{L}$ and $150 \mathrm{mmol} / \mathrm{L}$, respectively. It includes water of SP4 piezometer, affected by the wastewater and the infiltration of PG leachate relatively rich in $\mathrm{Na}^{+}$and $\mathrm{Cl}^{-}$(Table 2).

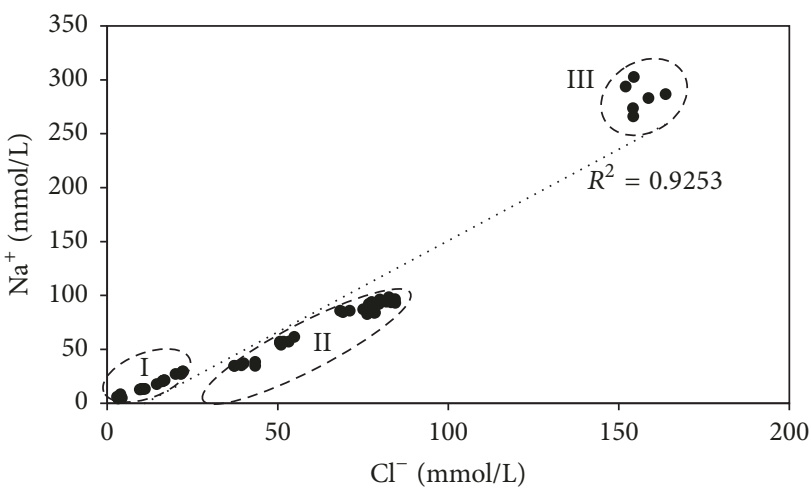

Figure 7: Plot of $\mathrm{Na}^{+}$against $\mathrm{Cl}^{-}$.

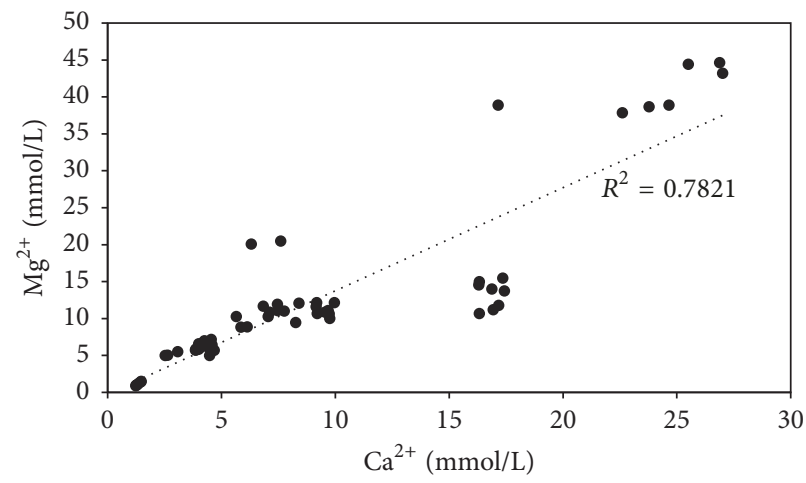

FIGURE 8: Plot of $\mathrm{Ca}^{2+}$ against $\mathrm{Mg}^{2+}$.

The enrichment in $\mathrm{Na}^{+}$and $\mathrm{Cl}^{-}$, from the upstream to the downstream, would be related to water-reservoir rock interaction, saline water infiltration from the evaporation ponds, and marine intrusion. During the study period, potassium concentrations are almost homogeneous at the same sampling location, with values ranging from 2.15 to $23.68 \mathrm{mg} / \mathrm{L}$. The concentrations of $\mathrm{Mg}^{2+}$, which fluctuate between 22.5 and $1085 \mathrm{mg} / \mathrm{L}$, are positively correlated to $\mathrm{Ca}^{2+}$ contents, with a determination coefficient of 0.78 , suggesting the same origin, which is the magnesian calcite dissolution (Figure 8). The highest values of the different majors elements are recorded during the dry season (October, August, and May), while the lowest values are recorded during the wet season (January and March). The slight variation is due to the dilution effect with fresh water in the recharge areas during the wet season and evaporation, during the dry season.

4.2.3. Orthophosphates and Fluorine Concentrations. Ortho$\mathrm{P}$ and fluorine concentrations fluctuate between 1.5 and $136.65 \mathrm{mg} / \mathrm{L}$ and between 0.5 and $29 \mathrm{mg} / \mathrm{L}$, respectively. Groundwater sampled near the PG discharge site showed high concentration levels of Ortho-P, which are larger in terms of extent and impact than those taken from the upstream part (Figure 9(a)). The highest levels of fluorine were measured in SP4 groundwater (Figure 9(b)). All shallow groundwater samples except $\mathrm{P} 1, \mathrm{P} 2$, and $\mathrm{P} 3$ contain $\mathrm{F}^{-}>$ $1.5 \mathrm{mg} / \mathrm{L}$, which is the WHO drinking water standard. The 


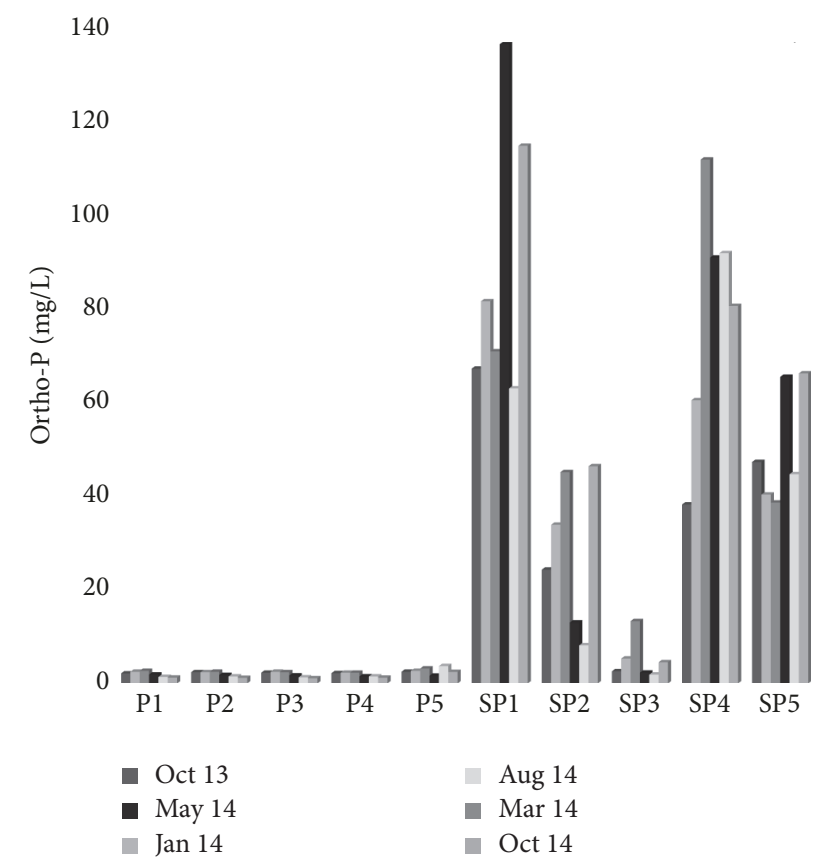

(a)

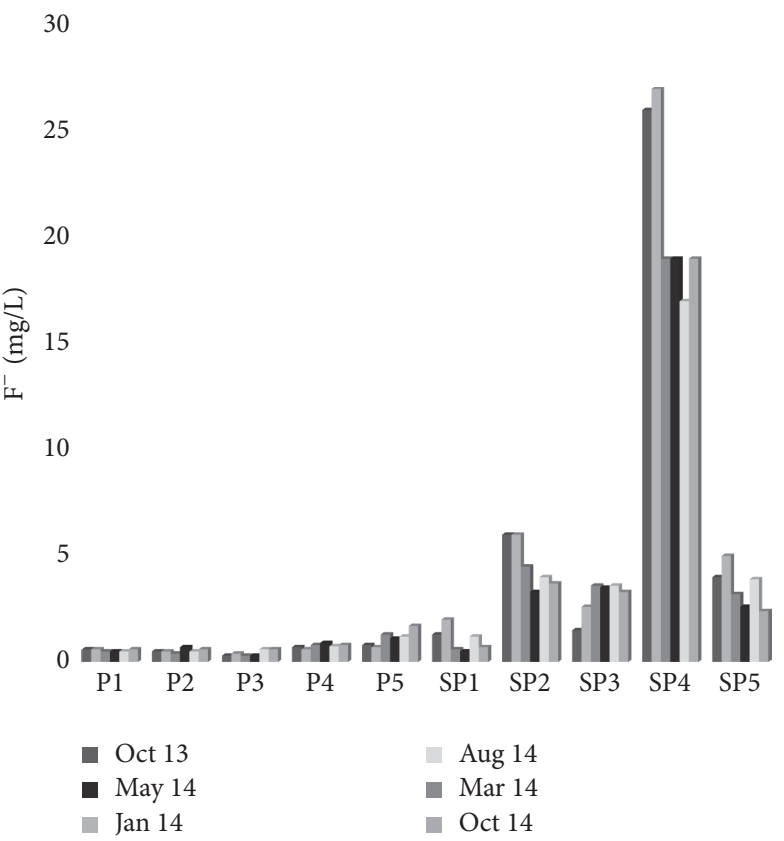

(b)

FIGURE 9: Distribution of orthophosphates (a) and fluorine (b) in Sfax-Agareb groundwater.

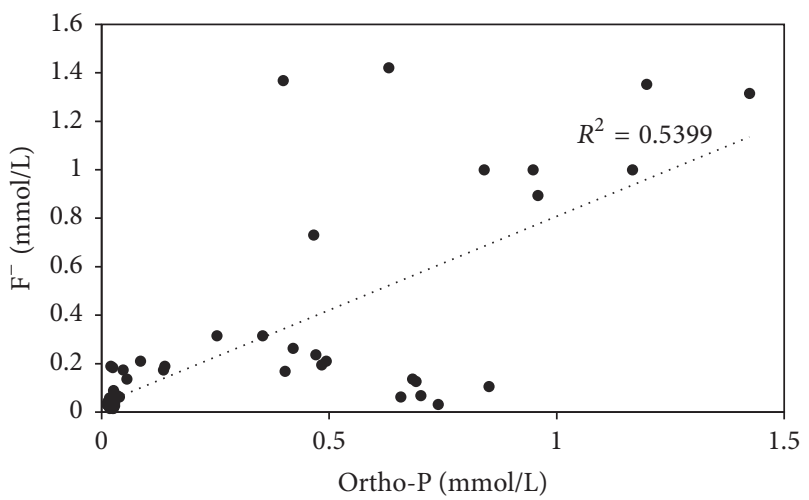

Figure 10: Plot of Ortho-P against fluoride.

spatial distribution of $\mathrm{F}^{-}$and Ortho-P contents is related to the diffusion resulting from the flow direction of the aquifer as well as the chemical transformations of the PG leachates in the unsaturated zone. A significant temporal variation was recorded, due to the dilution during the recharging period. Plot of Ortho-P against fluoride (Figure 10) shows tremendous correlation, around the PG dump, suggesting that these elements originate from PG leachate, which are highly concentrated in Ortho- $\mathrm{P}$ and $\mathrm{F}^{-}$(Table 2). On the other hand, groundwater of the upstream part does not show an evident correlation, which confirms the natural origin of these elements in this zone [31].

4.2.4. Trace Elements. The source of trace metals in the groundwater could be geogenic, but high concentrations above the permissible limit of drinking water standards raise the suspicions of industrial contamination sources [32]. The concentrations of $\mathrm{Zn}$ and $\mathrm{Al}$ in the study area varied from 0.02 to $1.51 \mathrm{mg} / \mathrm{L}$ and from 0.02 to $1.8 \mathrm{mg} / \mathrm{L}$, respectively. The higher contents of $\mathrm{Zn}$ were registered in SP4 piezometer, whereas the optimal concentrations of $\mathrm{Al}$ were measured in SP1 piezometer, which is located near the PG storage. For the majority of the sampled water, the $\mathrm{Cr}, \mathrm{Cd}$, and $\mathrm{Cu}$ contents do not exceed $0.05 \mathrm{mg} / \mathrm{L}$. Low levels of trace elements noticed in the majority of the analyzed water, despite the gypsum water contamination, are linked to the purifying function of soils. The mechanisms that allow transforming charged surface water with dissolved, mineral, or organic matter into less charged water form the purifying functions of the soil [33].

4.3. Statistical Analysis. To discuss the relationships between the physicochemical parameters, major elements, Ortho-P, and fluorine in groundwater samples, PCA was used to distinguish the contributions of the natural and anthropogenic processes to the Sfax-Agareb aquifer, in the site of TCG.

Two independent factors were extracted, which explain $83.77 \%$ of the total variance. The first factor (F1) presents $72.34 \%$ of the total inertia. It is defined by EC and the $\mathrm{Ca}^{2+}, \mathrm{Cl}^{-}, \mathrm{Na}^{+}, \mathrm{K}^{+}, \mathrm{Mg}^{2+}, \mathrm{HCO}_{3}{ }^{-}$, and $\mathrm{SO}_{4}{ }^{2-}$ contents in a less important measurement by Ortho-P and $\mathrm{F}^{-}$. These elements contribute to the mineralization of the groundwater in TCG site. The second factor (F2) explains $11.43 \%$ of the total variance with a strong loading with $\mathrm{pH}$ and dissolved $\mathrm{O}_{2}$ (Table 3). The spatial distribution of the variables (chemical parameters) and individuals (samples) in the axe systems F1F2 shows the presence of two water groups (Figure 11). 
TABLE 3: Summary of the PCA results including the loadings and the eigenvalues.

\begin{tabular}{lcc}
\hline Variables & Axe F1 & Axe F2 \\
\hline $\mathrm{Na}^{+}$ & 0.9902 & 0.0400 \\
$\mathrm{Cl}^{-}$ & 0.9537 & 0.2568 \\
$\mathrm{~K}^{+}$ & 0.9646 & -0.0319 \\
$\mathrm{Ca}^{2+}$ & 0.9162 & 0.2195 \\
$\mathrm{SO}_{4}{ }^{2-}$ & 0.7810 & -0.3565 \\
$\mathrm{Mg}^{2+}$ & 0.8930 & 0.3142 \\
$\mathrm{HCO}_{3}{ }^{2+}$ & 0.8782 & 0.4375 \\
$T^{\circ}$ & 0.1665 & -0.3803 \\
$\mathrm{pH}^{-}$ & -0.7253 & 0.6316 \\
$\mathrm{H}_{2} \mathrm{PO}_{4}{ }^{-}$ & 0.8026 & -0.3231 \\
$\mathrm{~F}^{-}$ & 0.8387 & 0.4741 \\
Dissolved $\mathrm{O}_{2}$ & -0.8304 & 0.3433 \\
$\mathrm{EC}$ & 0.9894 & 0.1067 \\
$\mathrm{Al}$ & 0.7383 & -0.4214 \\
$\mathrm{Zn}$ & 0.9474 & 0.0343 \\
Eigenvalues & 10.8513 & 1.7147 \\
$\%$ variance explained & 72.3422 & 11.4312 \\
$\%$ cumulative variance & 72.3422 & 83.7734 \\
\hline
\end{tabular}

TABLE 4: Isotopic and chloride composition of selected groundwater samples in October 2014.

\begin{tabular}{lccc}
\hline & $\delta^{18} \mathrm{O}(\%)$ & $\delta^{2} \mathrm{H}(\%)$ & $\mathrm{Cl}^{-}(\mathrm{mg} / \mathrm{L})$ \\
\hline P1 & -5.97 & -36.01 & 151 \\
P2 & -5.88 & -35.98 & 356 \\
P3 & -5.64 & -35.37 & 581 \\
P4 & -5.61 & -35.22 & 776 \\
P5 & -5.57 & -32.18 & 1739.5 \\
SP1 & -3.58 & -26.80 & 2627 \\
SP2 & -4.12 & -27.20 & 2130 \\
SP3 & -5.50 & -34.47 & 745.5 \\
SP4 & -3.65 & -26.10 & 5475 \\
SP5 & -4.10 & -26.88 & 2094.5 \\
Sfax rainwater & -4.60 & & 10 \\
Seawater & 0.00 & & 19000 \\
\hline
\end{tabular}

The PCA confirm the different geochemical correlation and classification of the Sfax-Agareb groundwater, in TCG site, into two types: groundwater samples collected from the downstream part, which are influenced by the anthropogenic processes, largely controlled by the PG leachate percolation and the seawater intrusion. Samples collected from the upstream part of the study area were principally controlled by the natural recharge, with no evidence of high anthropogenic impacts.

4.4. Stable Isotopes $\left({ }^{18} \mathrm{O},{ }^{2} \mathrm{H}\right)$. The stable isotope composition of water in the study area varies from $-5.97 \%$ to $-3.58 \%$ o $\mathrm{V}$-SMOW for $\delta^{18} \mathrm{O}$ and from $-36.01 \%$ o to $26.1 \%$ V-SMOW for $\delta^{2} \mathrm{H}$. The $\delta^{18} \mathrm{O}$ and $\delta^{2} \mathrm{H}$ values (Table 4 ), plotted in Figure 12 in relation to the Global Meteoric Water Line

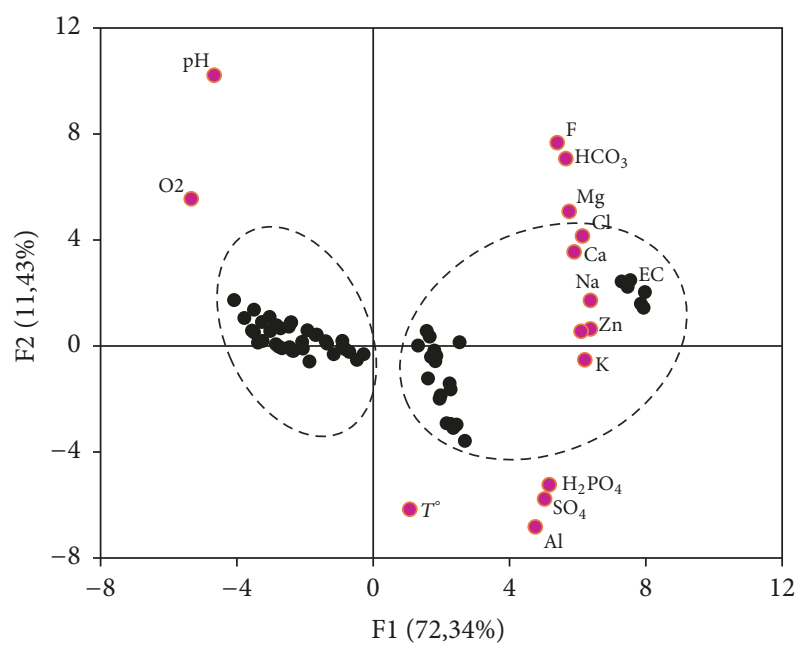

FIGURE 11: Spatial distribution of the variables and individuals in the axes system $\mathrm{F}$.

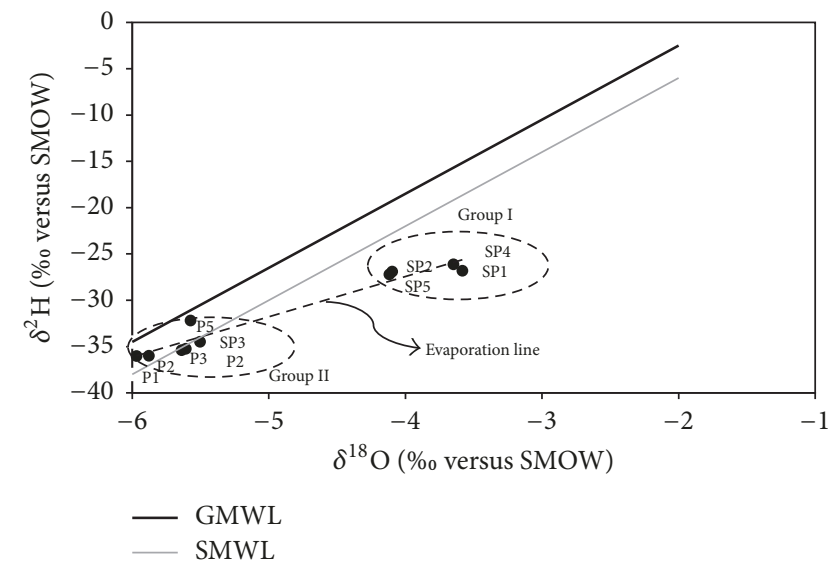

FIgURE 12: $\delta^{2} \mathrm{H}-\delta^{18} \mathrm{O}$ relationship of Sfax-Agareb groundwater.

(GMWL: $\delta^{2} \mathrm{H}=8 \delta 18 \mathrm{O}+10$ ) [34] and the Regional Meteoric Water Line of Sfax, Tunisia (SMWL: $\delta^{2} \mathrm{H}=8 \delta^{18} \mathrm{O}+13.5$ ) [35, $36]$, show that most of the groundwater samples are located below the GMWL and near the SMWL which indicates water evaporation in the unsaturated zone. Therefore, groundwater isotopic enrichment might be the outcome from evaporation of recent precipitation. This is facilitated by the sandy clay lithology of the unsaturated zone and the low depth of the piezometric level, which is less than $10 \mathrm{~m}$. The stable isotope signature of groundwater, in the study area, has identified two groups (Figure 12):

Group I is generated by the most enriched water in isotopes: SP1, SP2, SP4, and SP5 in the downstream part of the water table.

Group II involves water characterized by the lowest levels of $\delta^{18} \mathrm{O}$ and $\delta^{2} \mathrm{H}$ : P1, P2, P3, P4, and SP3 in the upstream part of the water table.

The $\delta^{18} \mathrm{O} / \mathrm{Cl}^{-}$diagram [37] confirms the groundwater distribution into two groups (Figure 13), weakly or strongly 


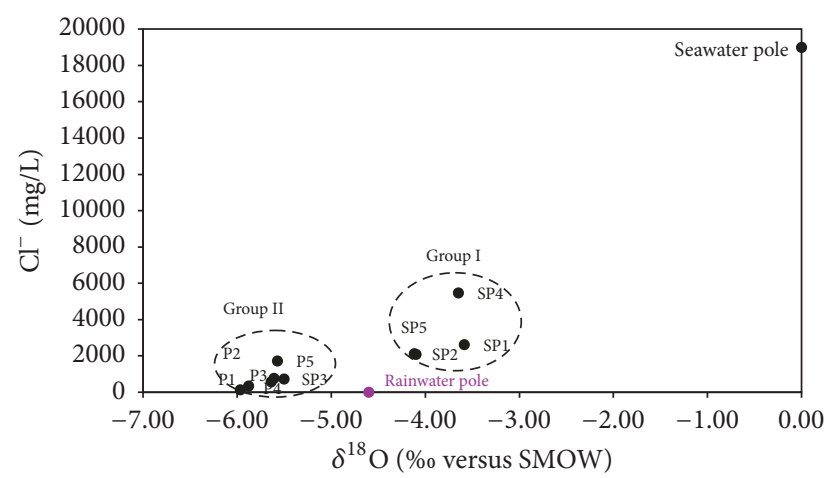

FIGURE 13: $\mathrm{Cl}^{-}-\delta^{18} \mathrm{O}$ relationship of Sfax-Agareb groundwater.

evaporated, which are distinguished by their chlorides and oxygen-18 contents. Indeed, the representative points of these two groups are located on either side of the rainwater pole, characterized by $\mathrm{Cl}^{-}$and $\delta^{18} \mathrm{O}$ contents, respectively, of $10 \mathrm{mg} / \mathrm{L}$ and 4, 6\%o V-SMOW.

The total dissolved solids of group I water, which are characterized by higher contents of $\mathrm{Cl}^{-}$and $\delta^{18} \mathrm{O}$ than those of rainwater, but lower than those of seawater, are related, in part, to evaporation.

\section{Conclusion}

The geochemical study of the major elements, Ortho- $\mathrm{P}, \mathrm{F}^{-}$, trace elements, and stable isotopes, elucidated the influence of PG leachates and laid emphasis upon the natural factors intervening in altering the groundwater chemistry of the Sfax-Agareb aquifer. Temporal variation was recorded due to dilution during the recharging period in winter. The groundwater mineralization is related to water-rock interaction processes, saline water, and PG leachates infiltration coupled with marine intrusion. Groundwater below the PG dump and in the downstream part of the aquifer showed the highest concentrations of Ortho- $\mathrm{P} \mathrm{F}^{-}, \mathrm{SO}_{4}{ }^{2-}$, acidity, and total dissolved solids, which significantly exceed those relevant to the upstream water. Spatial distribution of these contents is presumably related to the diffusion that ensues the flow direction of the aquifer and the water-rock interaction. The groundwater quality is severely deteriorating in the downstream part of the Sfax-Agareb aquifer especially by $\mathrm{Zn}$ and $\mathrm{Al}$. The stable isotope data attests that water of the Sfax-Agareb aquifer originated from recent rainwater has evaporated in the unsaturated zone. The result of this study will be helpful for a proper water development and for remediation of strategies to decrease the pollution source.

\section{Conflicts of Interest}

The authors declare that they have no conflicts of interest.

\section{References}

[1] S. M. Yidana and A. Yidana, "Assessing water quality using water quality index and multivariate analysis," Environmental Earth Sciences, vol. 59, no. 7, pp. 1461-1473, 2009.
[2] H. Vijith and R. Satheesh, "Geographical Information System based assessment of spatiotemporal characteristics of groundwater quality of upland sub-watersheds of Meenachil River, parts of Western Ghats, Kottayam District, Kerala, India," Environmental Geology, vol. 53, no. 1, pp. 1-9, 2007.

[3] E. Custodio and G. A. Bruggeman, "Groundwater Problems in Coastal Areas," in Studies and Reports in Hydrology, vol. 45, UNESCO, 1987.

[4] W. M. Edmunds, A. H. Guendouz, A. Mamou, A. Moulla, P. Shand, and K. Zouari, "Groundwater evolution in the Continental Intercalaire aquifer of southern Algeria and Tunisia: trace element and isotopic indicators," Applied Geochemistry, vol. 18, no. 6, pp. 805-822, 2003.

[5] M. Ketata, F. Hamzaoui, M. Gueddari, R. Bouhlila, and L. Ribeiro, "Hydrochemical and statistical study of groundwaters in Gabes-south deep aquifer (south-eastern Tunisia)," Physics and Chemistry of the Earth, vol. 36, no. 5-6, pp. 187-196, 2011.

[6] A. Sherif and D. Dadi, Tunisia- Degradation Cost of water resources of the Medjerda Bassin. Sustainable Water Integrated Management (SWIM) Support Mechanism, Project funded by the European Union, 2012.

[7] P. M. Rutherford, M. J. Dudas, and R. A. Samek, "Environmental impacts of phosphogypsum," Science of the Total Environment, The, vol. 149, no. 1-2, pp. 1-38, 1994.

[8] H. T. Fukuma, E. A. N. Fernandes, and A. L. Quinelato, "Distribution of natural radionuclides during the processing of phosphate rock from Itataia-Brazil for production of phosphoric acid and uranium concentrate," Radiochimica Acta, vol. 88, no. 9-11, pp. 809-812, 2000.

[9] P. P. Haridasan, C. G. Maniyan, P. M. B. Pillai, and A. H. Khan, "Dissolution characteristics of 226Ra from phosphogypsum," Journal of Environmental Radioactivity, vol. 62, no. 3, pp. 287294, 2002.

[10] E. A. Abdel-Aal, "Crystallization of phosphogypsum in continuous phosphoric acid industrial plant," Crystal Research and Technology, vol. 39, no. 2, pp. 123-130, 2004.

[11] C. Papastefanou, S. Stoulos, A. Ioannidou, and M. Manolopoulou, "The application of phosphogypsum in agriculture and the radiological impact," Journal of Environmental Radioactivity, vol. 89, no. 2, pp. 188-198, 2006.

[12] T. Bituh, G. Marovic, Z. Franic, J. Sencar, and M. Bronzovic, "Radioactive contamination in Croatia by phosphate fertilizer production," Journal of Hazardous Materials, vol. 162, no. 2-3, pp. 1199-1203, 2009.

[13] C. Roselli, D. Desideri, and M. A. Meli, "Radiological characterization of phosphate fertilizers: Comparison between alpha and gamma spectrometry," Microchemical Journal, vol. 91, no. 2, pp. 181-186, 2009.

[14] P. Chauhan, R. P. Chauhan, and M. Gupta, "Estimation of naturally occurring radionuclides in fertilizers using gamma spectrometry and elemental analysis by XRF and XRD techniques," Microchemical Journal, vol. 106, pp. 73-78, 2013.

[15] R. Trabelsi, M. Zairi, and H. B. Dhia, "Groundwater salinization of the Sfax superficial aquifer, Tunisia," Hydrogeology Journal, vol. 15, no. 7, pp. 1341-1355, 2007.

[16] INM, "National Institue of Meteorology, climate data report for the period 2005-2015," 2015.

[17] M. Ben Akacha, Etude géologique de la région dAgareb-Sfax Evolution géomorphologique, néotectonique et paléogéologique [Master, thesis], University of Sfax, Sfax, Tunisia, 2001. 
[18] P. F. Burollet, "Contribution à létude stratigraphique de la Tunisie Centrale., Tunisia," Annuaire Géologique des Mines, 1956.

[19] R. Trabelsi, Contribution à létude de la saliniation des nappes phréatiques côtières. Cas du système de Sfax-Mahdia [Ph.D. thesis], 2008.

[20] M. Takrouni and J. Michelot, "Relation entre aquifère profond, nappes superficielles et intrusion marine dans le bassin de Sfax (Tunisie)," Hydrogeology of the Mediteranean and Semi-arid Regions, vol. 278, pp. 477-483, 2003.

[21] J. Rodier, L'analyse de l'eau. Eaux naturelles, eaux résiduaires, eau de mer. Dunod, 8th edition, 2005.

[22] Y. Ait Brahim, A. Benkaddour, M. Agoussine, A. Ait Lemkademe, L. A. Yacoubi, and L. Bouchaou, "Origin and salinity of groundwater from interpretation of analysis data in the mining area of Oumjrane, Southeastern Morocco," Environmental Earth Sciences, vol. 74, no. 6, pp. 4787-4802, 2015.

[23] R. Ben Amor and M. Gueddari, "Major ion geochemistry of Ghannouch-Gabes coastline (at Southeast Tunisia, Mediterranean Sea): study of the impact of phosphogypsum discharges by geochemical modeling and statistical analysis," Environmental Earth Sciences, vol. 75, no. 10, article no. 851, 2016.

[24] S. Sahu, P. Ajmal, R. Bhangare, M. Tiwari, and G. Pandit, "Natural radioactivity assessment of a phosphate fertilizer plant area," Journal of Radiation Research and Applied Sciences, vol. 7, no. 1, pp. 123-128, 2014.

[25] L. Ã. Reijnders, "Cleaner phosphogypsum, coal combustion ashes and waste incineration ashes for application in building materials: a review," Building and Environment, vol. 42, no. 2, pp. 1036-1042, 2007.

[26] B. Tlili Zrelli and M. Gueddari, "Groundwater hydrogeochemistry of Mateur Alluvial Aquifer (Northern Tunisia)," Journal of Hydrogeology and Hydrologic Engineering, vol. 05, no. 01, 2016.

[27] C. Appelo and D. Postma, Geochemistry, Groundwater and Pollution, Second Edition, Taylor \& Francis, 2005.

[28] H. C. Helgeson and D. H. Kirkham, "Theoretical prediction of the thermodynamic behavior of aqueous electrolytes at high pressures and temperatures; II, Debye-Huckel parameters for activity coefficients and relative partial molal properties," American Journal of Science, vol. 274, no. 10, pp. 1199-1261, 1974.

[29] M. Gueddari, Géochimie et thermodynamique des évaporites continentals, étude du lac Natron en Tanzanie et du Chott El Jrid en Tunisie. Thesis, University of Louis Pasteur, Strasbourg, 1984.

[30] D. L. Parkhurst and C. A. J. Appelo, "Description of input and examples for PHREEQC version 3-a computer program for speciation, batch-reaction, one-dimensional transport," in and inverse geochemical calculations: U.S. Geological Survey Techniques and Methods, Book 6, Chap. A43, p. 497, and inverse geochemical calculations, U.S. Geological Survey Techniques and Methods, 2013.

[31] S. Melki and M. Gueddari, "Impact Assessment of Phosphogypsum on the Groundwater of Sfax-Agareb Aquifer," in Proceedings of the in Southeast of Tunisia. ICEWE 2017 : 19th International Conference on Energy, Water and Environment. World Academy of Science, Engineering and Technology International Journal of Energy and Power Engineering Vol:11, 2017.

[32] A. G. S. Reddy, B. Saibaba, and G. Sudarshan, "Hydrogeochemical characterization of contaminated groundwater in Patancheru industrial area, southern India," Environmental Modeling \& Assessment, vol. 184, no. 6, pp. 3557-3576, 2012.
[33] B. J. Alloway, Heavy metals in soils, Blackie Academic \& Professional, London, 2nd edition, 1995.

[34] H. Craig, "Isotopic variation in meteoric waters. Science," in Groundwater Problems in Coastal Areas, vol. 45 of Studies and Reports in Hydrology, pp. 1702-1703, 1987.

[35] A. Maliki, Etude hydrogéologique, hydrochimique et isotopique de la nappe profonde de Sfax [Ph.D. thesis], University of Sfax, Sfax, Tunisia, 2000.

[36] H. Jeanton, K. Zouari, Y. Travi, and A. Daoud, "Caractérisation isotopique des pluies en Tunisie. Essai de typologie dans la région de Sfax," Earth and Planetry Science Letters, vol. 333, pp. 625-631, 2001.

[37] I. D. Clark and p. p. Fritz, Environmental isotopes in hydrology, CRC Lewis, Boca Raton, FL, USA, 1997. 

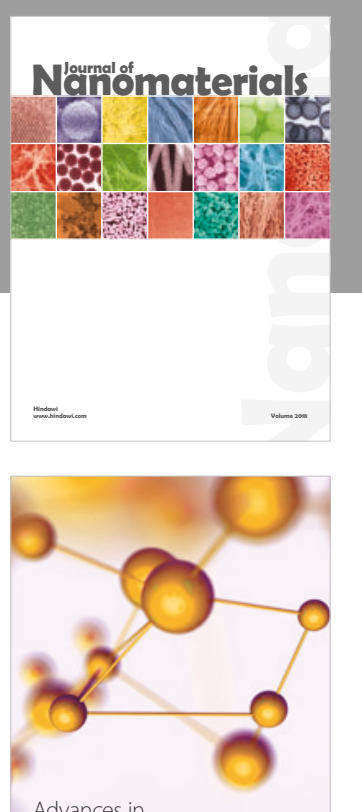

Physical Chemistry
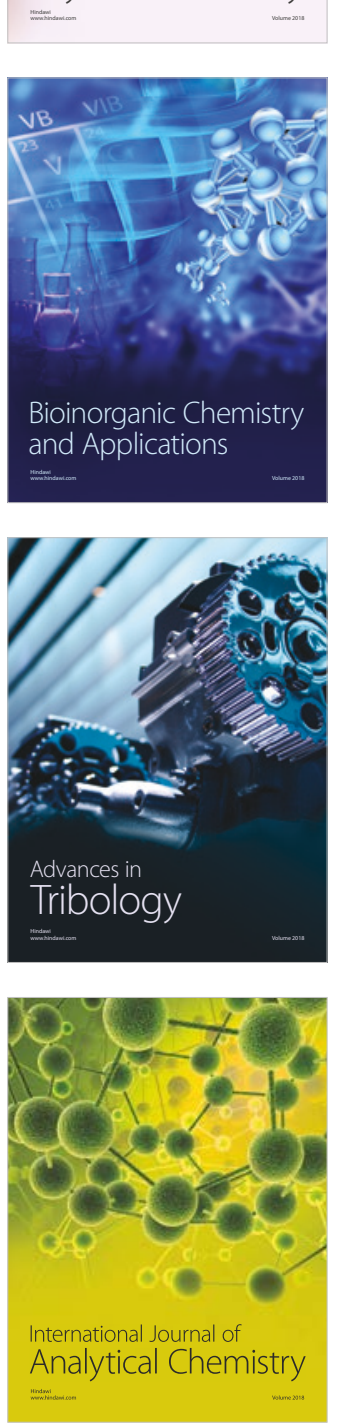

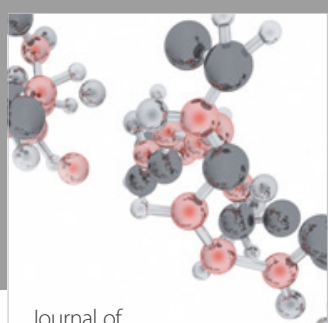

Analytical Methods

in Chemistry

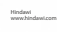

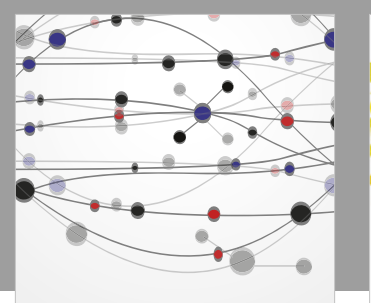

The Scientific World Journal

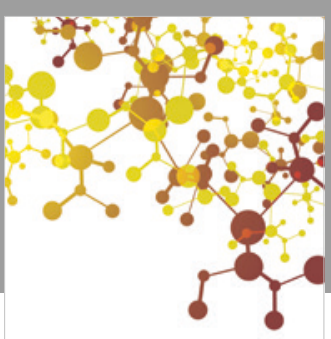

Journal of

Applied Chemistry
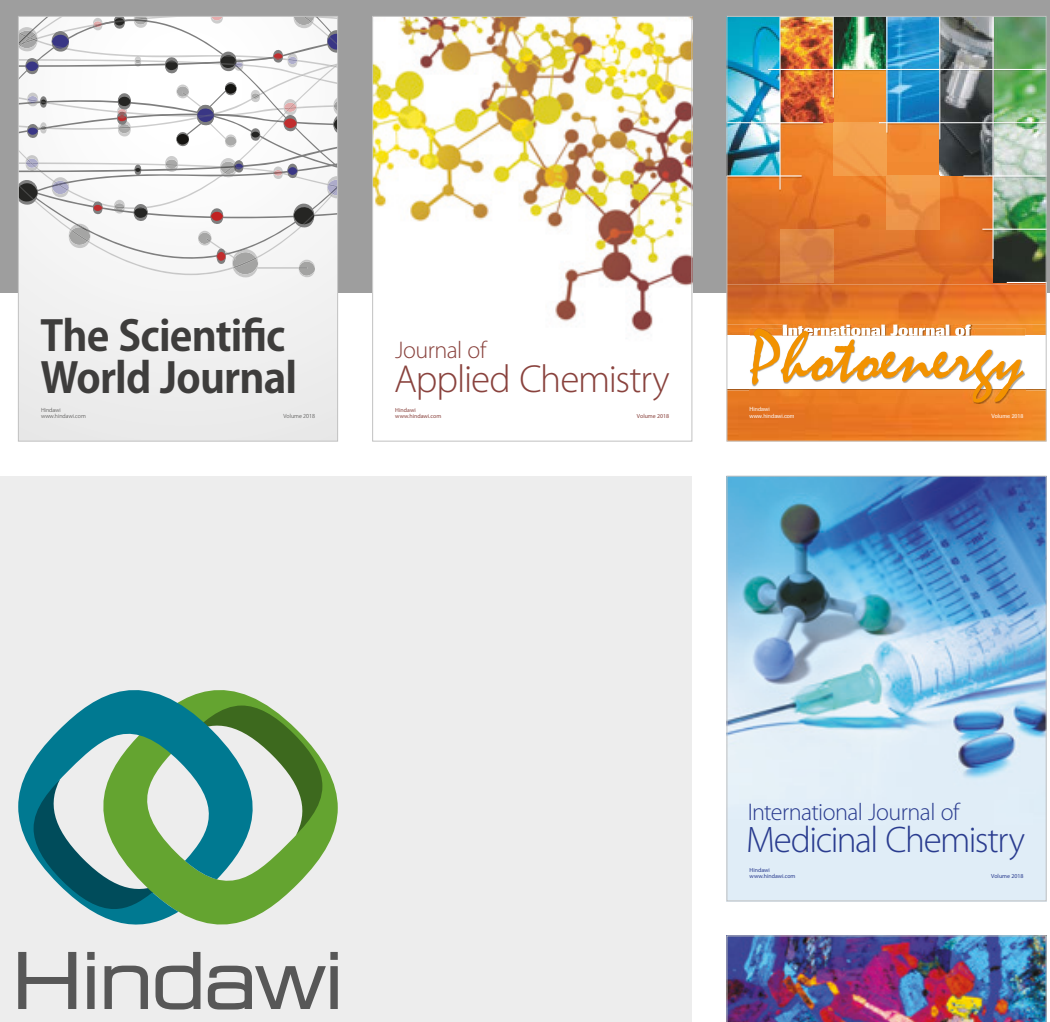

Submit your manuscripts at

www.hindawi.com
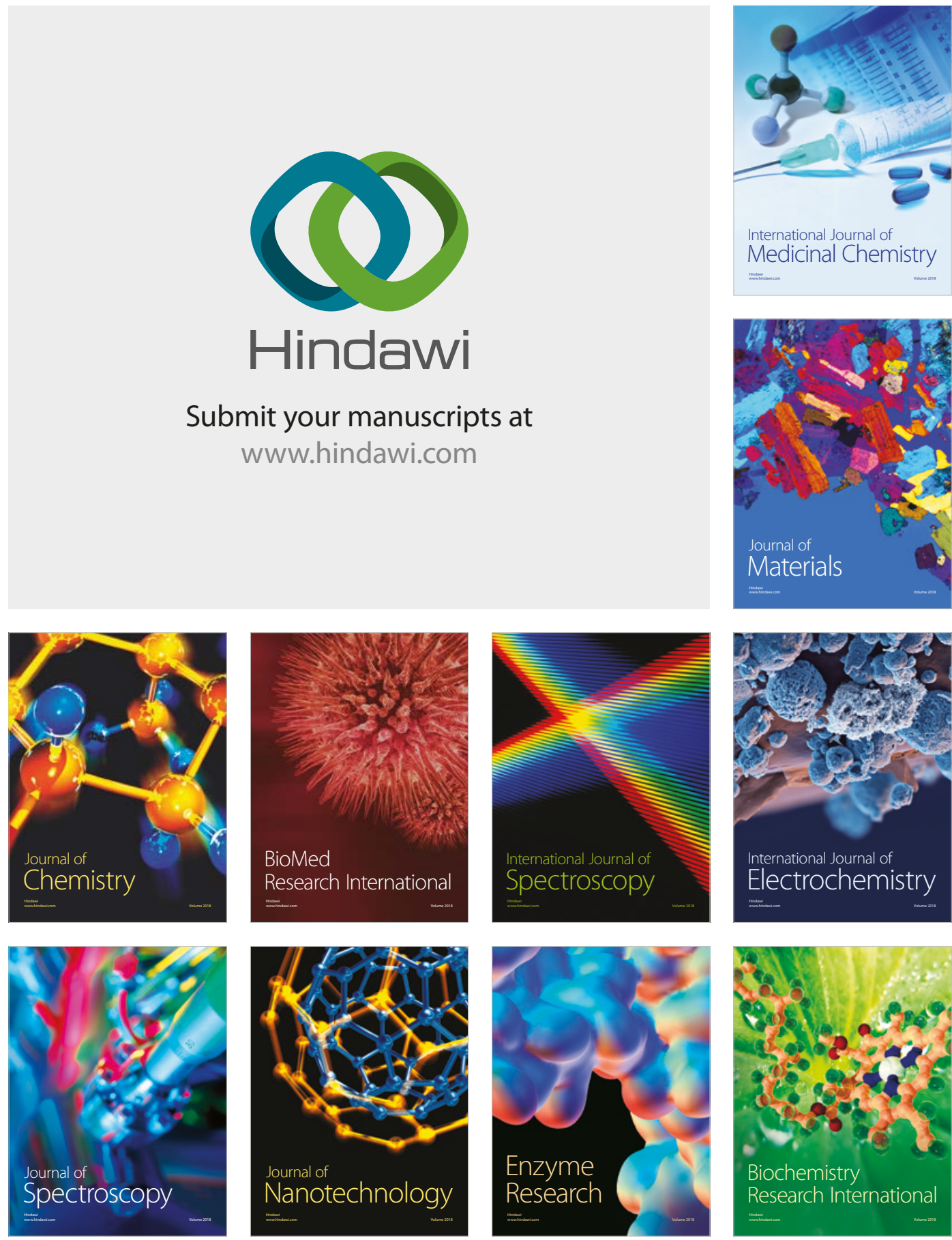
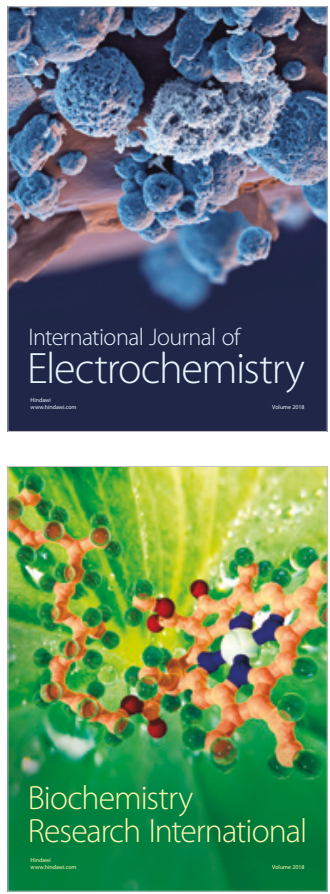